\title{
The evolution of tourism in the digital era: the case of a tourism destination ${ }^{1}$
}

\section{Fabiana Sciarelli - Valentina Della Corte \\ Giovanna Del Gaudio}

\begin{abstract}
Purpose of the paper: This paper studies the recent changes in the tourism business because of the increasing amount of information on the web and the consequent level of uncertainty and complexity, both for the demand and for the firms.

Methodology: This paper systematises the process of evolution in tourism in the digital era and its consequences for tourist destinations. The topic is verified empirically through a panel of experts and case study methodology to study the experts' opinions on the process, with reference to the city of Naples.

Findings: The tourism sector has been one of the first mover sectors in ICT and digital development, with consequent evolution of the value chain and businessto-consumer relationships. The growing amount of available information has paradoxically generated an 'informative syndrome', which at times makes these relationships more difficult and complex.

Research limits: This paper indicates the limit of studying the issue with reference to a single case study. It represents a first step of wider research that will require further analysis, both in terms of the number of case studies and with reference to demand.

Practical implications: The quality of information and professionalism are of fundamental importance in a sector characterised by dynamism and turbulence. Marketing policies require a total revision both for firms and for tourist destinations.

Originality of the paper: This paper considers numerous aspects of the tourism sector, both on the offer and demand side. Its originality derives from the analysis of the evolution of this sector for tourists and firms, in the face of the informative syndrome issue.
\end{abstract}

Key words: tourism evolution; digital era; informative syndrome; fake competitive news

\section{Introduction}

In the digital age, tourism has been and remains a booming economic sector. This applies to both domestic and international tourism, and encompasses the main tourist destinations around the world. According to recent research, it is expected that people travelling abroad (which

1 For the realization of this work, thanks to: Gesac Capodichino, Federalberghi Napoli, Cimatour, Starhotels SPA, Fiavet Campania, Unione Industriali Tourism Division (Naples) and Prof. Sergio Sciarelli, constant example of guidance and rigor in scientific activity. 
sinergie Vol. 36, N. 105, 2018

account for 700 million today) will become 1.8 million by 2030 (World Trade Organization, 2016). These data are the result of a set of favourable factors that are able to balance and overcome the unfavourable factors (particularly terrorism and economic crisis). Throughout this growth in tourism flows, the progress of information technology has played, and will continue to play, a fundamental role. In this regard, in 2015, online travel reached the value of $\$ 500$ billion, with an increase of $11 \%$ per year (World Trade Organization, 2016). These numbers are significant and will expand exponentially in the future (since the beginning of 2017, it has been estimated that one in every two vacations is booked online). Airbnb reached 300,000 customers in 2017, offering 45 million houses in 81 million cities, and expecting to reach one million customers by 2028 (Il Sole 24 Ore, 28/02/2018). This process has been progressively enriched by the creation and development of social networks, and by the increasing use of mobile telephones as multifunctional tools. Today, Web 4.0 refers to an intelligent web that is able to enhance the user's experience (Wei, 2013). These factors have expanded the level of knowledge about tourist destinations, with relative offers, and have enabled the masses ready access to the tools and information to select from a variety of choices. The multiple factors interplaying in this sector and the overlapping perspective between demand and offer have rendered the evolution of tourism more dynamic and unpredictable. In particular, some factors occupy a central position within the evolutionary scheme of tourism, including the increasing amount of information, the variability in demand and the hyper-competition of the offer (Coshall, 2009; Michopoulou and Buhalis, 2008).

However, while the increasing amount of information has widened the knowledge of potential tourists, it has also increased the complexity of the choices, and caused increased difficulty in performing a systematic information search. All these factors have upset the sector, in line with the forecasts of previous contributions (Sciarelli and Della Corte, 2011).

With reference to the offer side, there has been a real revolution in the relationships within the value chain, even compromising the role and survival of some traditional firms, and thereby changing their pivotal positions and relative activities (for example, some airline companies and even tourist destinations-rather than internet providers-offer very powerful destination management systems).

Meanwhile, the demand side tends to assume the characteristics of greater variability and unpredictability. The methods and tools used to acquire information have impressively changed over time, and the main decisions and evaluations appear to be influenced much more by word of mouth or clicks within social networks, as expressions of the tourist experience (Coshall, 2009).

In such a scenario, the complexity of the decision-making process depends on a complex set of behavioural patterns (Decrop, 1999; Han et al., 2009), alternatives (McCabe et al., 2017) and interactions (Smallman and Moore, 2010) between demand (tourist) and offer (different players in the tourism industry), as well as depending on social, economic, political, technological and environmental factors (such as terroristic attacks, environmental disasters and political instability). 
Within the evolution of the tourism sector (changes in demand), this paper analyses, both theoretically and empirically (through a panel of experts), the problem of the increasing amount of information for consumers, and the effect of the consequent complexity deriving from the sometimes excessive amount of faithful/unfaithful 'reviews' (including fake news-often used as a competitive weapon) on the behaviours of demand, as well as on the evolution of the offer side. In particular, the sector has been widely covered by digitalisation (now labelled as Industry 4.0) (Chiarini and Vagnoni, 2017), according to a process that has revolutionised the behavioural schemes of the demand side, and the value chain relationships of the offer side (De Nisco et al., 2012; Napolitano and De Nisco, 2004). This has also changed the approaches to promoting tourist destinations.

This paper analyses the evolution of the tourism sector with a glimpse into the changes in the roles of the actors in the value chain, as well as in the business-to-consumer relationships. This paper presents a literature review on the topic to verify the existence of eventual gaps. As discussed in the next section, some of our questions have not yet been answered; thus, we used these as research questions. On this basis, we decided to test our critical analysis with experts/operators from the tourism sector, concentrating on the city of Naples. This first step has been pivotal before conducting a specific analysis of the demand.

\section{Literature review}

Nowadays, information and communications technology (ICT) is not only important for travel purchases, but also because of the influence of online information and reviews (Buhalis and Law, 2008) on the 'planning process, including pre-, during-, and post-trips' (Simeon et al., 2017). This is the reason that the topic of 'informative syndrome' must be dealt with as an overlapping perspective between demand and supply. The word 'syndrome' derives from the ancient Greek term ' $\sigma v v \delta \rho o \mu \eta \eta$ ', which, in the medical field, refers to a set of symptoms occurring altogether, constituting a serious disorder. As a consequence, specialist doctors must analyse these symptoms to determine the appropriate therapy to alleviate them.

As in medicine, the 'informative syndrome' in the tourist decisionmaking process consists of a series of manifestations that are evidence of identifiable patterns and causes (e-word of mouse, word of mouth, terroristic attacks and environmental damages). Informative syndrome expresses an excess of factors that, in this case, are connected with the redundancy and sometimes excess of information available on the internet. This is the reason that tourist managers must understand and monitor this process to determine the correct strategies to promote and commercialise their destinations. Hence, the case of online reviews has changed the way people search for information (Fotis et al., 2012; Pan and Fesenmaier, 2006) and has influenced effective choices and decisions to visit a destination.

Some studies have demonstrated that one-third of potential visitors use online opinions to obtain information about a destination (Gretzel and Yoo, 2008) because they assert that online reviews are the best informative
Fabiana Sciarelli
Valentina Della Corte
Giovanna Del Gaudio
The evolution of tourism in
the digital era: the case of a tourism destination 
sinergie Vol. 36, N. 105, 2018

means to select a destination. More precisely, potential tourists use the online reviews of tourists that have already experienced the destination as the main source of information before making a final decision (Gretzel and Yoo, 2008). The growing complexity of tourists' choices and the process of purchase (how the decision-making process is developed) seriously influence the management of tourist destinations and tourist firms.

In regard to the critical points of the offer, the excessive weight placed on reviews, big data analysis and user profiling activity have generated excessive demand dependency (Fuchs et al., 2014). This has required the development of different skills and expertise (such as analytics, information and technology managers). In this process of increasing chaos, redefinition of roles and repositioning, destination management plays a key role through its ability to build and transmit a destination image characterised by increasingly distinctive, unique, exclusive and emotional traits that are able to convey special and non-replicable experiences.

Tourist products that are intangible and difficult to evaluate before purchase (Casaló et al., 2015; Della Corte, 2013) have generated new ways of exchanging information through travel communities, social networks and online travel agencies (Brunetti et al., 2011). Meanwhile, the information and knowledge offered by tourists through ICT allow destination management organisations to better understand the strengths and weaknesses of their destinations (Kim et al., 2007; Simeon et al., 2017; Xiang and Gretzel, 2010).

In this scenario, in the supply chain, we can identify four main innovations in response to the evolution of demand ( $\mathrm{Li}$ et al., 2006; Wu et al., 2012): more incisive presence on the web and social networks, differentiation of value proposals addressed to users, increase in people's mobility and lower prices.

The digital expansion has imposed an adequate 'web presence' (including the preparation of sites and participation in social networks) of destinations, hotel facilities and transport carriers to be able to offer the innovations required by demand and to share information with customers (Hays et al., 2013; Mich, 2011; Mich et al., 2003).

Web marketing has contributed to the development of demand in three directions. It has created the stimulus for connection with potential customers, built a relationship of trust with appropriate guarantees, and implemented both pull and push strategies to improve the quality of information (Rita, 2000). The result of web activities can be positive or negative in terms of brand image related to destinations, accommodation facilities and so forth. The above distinction appears to be particularly important because it enables the understanding of the possible unfavourable influences that social networks can have on the quality of informationeither exalting false benefits or hiding the real benefits.

Continuing the examination, the second positive aspect in the evolution of the offer is represented by the increasing differentiation of products, with more personalised proposals (travel organisation even for small groups of travellers) as an answer to the increased segmentation of demand (Duman and Kozak, 2010). The differentiation of the offer favoured by the web has represented, and will represent in the future, a valid product 
policy. However, the latter will be favoured by the creation of transversal networks resulting from stronger application of the brand extension policy (Brondoni, 2000).

The third positive aspect for tourism development is undoubtedly the progress made in both domestic and international mobility (Puar, 2002). The increase in air transport (especially point-to-point connections), the speed and convenience of railway connections and the strengthening of motorway networks have had very favourable influences on the accessibility of a growing number of destinations, and have contributed significantly to the development of both domestic and international tourism (Bieger and Wittemer, 2006).

The fourth main factor in the evolution of supply is linked to more a effective use of the price lever. This is in the case of differentiation of tariffs and the ability to offer cheaper quotes-albeit with minor ancillary services (the classic example is that of low-cost airfares)-and application of particularly discounted prices for very early bookings (Mangion et al., 2005). In general, an overall foreign attention on the quality/price relationships of the provided services is required.

All these aspects have influenced firm-specific activities in the value chain, as well as their relative role.

\section{Evolution of the tourism chain}

Analysing the digital economy indicates that the overall effect of the 'disintermediation' process (Stamboulis and Skayannis, 2003) in the tourism value chain has seen a dramatic change. Figure 1 displays how strategic marketing activities have evolved during the last 20 years.

During the early-stage years of 1996 to 2000 in figure 1, there existed a classical scheme that began with the destination with all of its connected tourist services. This "productive" system then interacted with the distribution channels, made of tour operators (in this phase considered wholesalers) and travel agencies. In this model, the business-to-business relationships played a key role in meeting the customer.

The symbolic date of the early-stage framework is 1996, when the online travel agency started to appear (Expedia was born in 1996, while Priceline appeared in 1997) and online tickets began being used. Hence, on this date, tourists started to autonomously purchase the components of travel, which reinforced the increase of the 'do it yourself' ('DIY') tourist (Franch et al., 2001). At this stage, the communication of tourist services was mainly managed by travel agents, despite the phenomenon of 'disinterested' word of mouth being present at all steps of the process.

During the in-between stage (2001 to 2006), the framework was more complex than in the previous stage, because distribution and communication started to be interrelated, and not only overlapping. In this stage, the first differentiation appeared in terms of tourists' typologies (DIY and dynamic packaging), which arose to create two parallel and coexisting channels of promotion and distribution. The tourist package followed a path that was very similar to the traditional process stage seen before, with the difference that it began using the internet to search information. The
Fabiana Sciarelli

Valentina Della Corte

Giovanna Del Gaudio

The evolution of tourism in

the digital era: the case of a

tourism destination 
sinergie

italian journal of management Vol. 36, N. 105, 2018
DIY tourist instead used internet providers to research information and make purchases, thereby proposing an apparent overlap of the functions. Even more, the DIY tourist used the internet for both functions, yet not necessarily the same providers.

Fig. 1: Tourism process stages
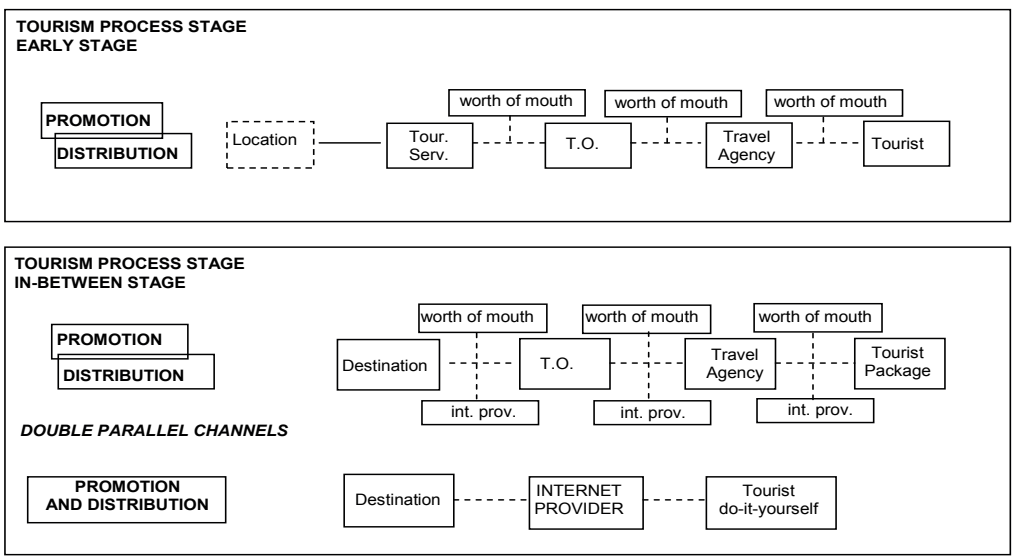

TOURISM PROCESS STAGE

CURRENT STAGE

INTEGRATED MULTIPLE CHANNELS

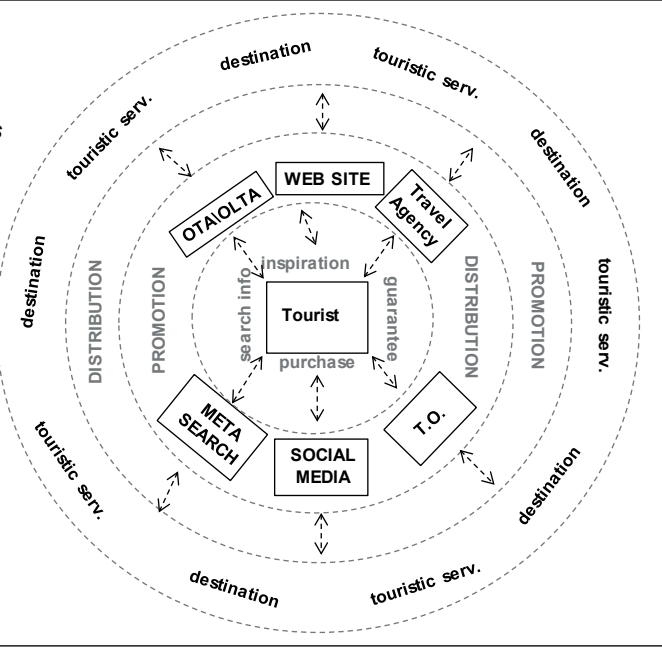

Source: our elaboration.

Distribution and communication were characterised by the multichannel strategy (Koo et al., 2011). At the end of the in-between stage, destinations started to commercialise their offers through tour operators and destination management systems, and this phenomenon led to the definition of multiple integrated channels.

In regard to the current stage, from the offer side, the framework shows: - A complete overlap between the communication and distribution process (Buhalis and O'Connor, 2005). In the past, even if some channels-such as TripAdvisor or Google-were only specialised in communication, they now also act as distribution channels, and vice versa (booking). 
- The components of the real offer, such as the travel agencies, are addressed to a virtual offer, in the formula of dynamic packaging either proposed by tour operators (or online travel agiencies) or, in a broader sense and out of the real scheme of packaging, by airline companies' websites (Della Corte, 2013; Mich et al., 2004).

- The offer has become more differentiated and huge. As aforementioned, some specific factors contribute to this variety: the progress of the means of transport, long-distance travel, low-cost strategies applied by many companies, some destinations becoming 'accessible' (Prideaux, 2000) even if the prices were high in the past, technology online opens to a wider market, since it can be reached by more targets on the demand side and used also by micro and small companies on the offer side.

- The sources of both information and distribution are shaped by a plurality of actors that can create confusion in the tourist's mind (Sigala, 2011; Urry, 2003). Nowadays, tourists are aware of the vastness of booking channels (Hadjikakou, 2013). Internet providers have also become a source of inspiration because they allow consumers to choose where to go, on the basis of travel costs.

- The overabundance of available information has determined the need for new human resources and schemes that can organise and systematise the existing information (Wöber, 2003).

From the demand side, the model highlights:

- The union between the type of package tourist and 'DIY' system. Previous existing differences are now less evident because they can be confused with each other until the stage of purchase (Luque-Martínez et al., 2007). In both cases, tourists use information available on the internet to find inspiration and necessary information for their choice, and verify the information received on the internet by a tour agenteither real or online.

- The guarantee on one side (tour operators and online travel agencies) and the risk (Kozak et al., 2007) on the other side (dynamic packaging displayed by airline companies and so forth).

- Tourists can gain direct access to a tourist product by using a destination management system that simultaneously promotes and gathers firms' proposals of commercialisation regarding the destination (Morgan et al., 2007).

Today, the web offers an open logic, whereby tourists not only search for information and acquire travel tickets, but also find sources of inspiration and guarantee. However, they also often experience great difficulty in understanding which information is reliable, among the many information sources and information overload.

\section{Why is there a problem of information 'syndrome'?}

Considering the digital revolution, travellers now require a series of pieces of information on the destinations and services to select (Fuchs and Reichel, 2011). In particular, the focus on the destination, whose
Fabiana Sciarelli

Valentina Della Corte

Giovanna Del Gaudio

The evolution of tourism in

the digital era: the case of a tourism destination 
sinergie Vol. 36, N. 105, 2018

promotion is mainly entrusted to public bodies, is often the first step in the decision-making process, since the destination must essentially represent the 'umbrella brand' for the entire trip (Pike, 2009).

Over the last 20 years, the search for information has become simpler, but more complex at the same time. The sources of information are much more numerous (internet, specialised magazines, surveys on countries to visit, daily press, sites to be consulted, television and film services). However, the negative consequence is the occurrence of a sort of informative syndrome for those who must make choices. The fundamental problem of research is not only collecting and processing the necessary data from various sources, but also knowing how to discern reliable data, thereby avoiding the risk of making choices based on poor information (Buhalis and Law, 2008). This involves a selection process that is neither simple nor quick.

Nowadays, the tourist, although benefiting from the use of digital tools, runs the risk of being submerged by data, news and facts (Livitin et al., 2008). This phenomenon is considered an effect of two causes that are somewhat interdependent: the difficulty and variety of the factors on which to base knowledge because of the multiplication of information sources, and the lower reliability of some of these sources (Livitin et al., 2008). The obviously negative consequence is that, to eliminate uncertainty and reduce risks, the tourist, while being able to take advantage of a broader range of information, must be able to evaluate factors of nonhomogeneous quality. This is mainly because of the inclusion in the market of so-called 'influencers', who are able to guide and often condition demand. The judgements and so-called 'reviews' widely available in social networks are not always objective and can unfortunately weigh on the final choices of the consumer. The phenomenon is attributable mainly to people who are well-known on the web ('web stars') and can be exacerbated by the participation of organisations specialised in building partisan opinions that aim to propose offers that are not always for the benefit of tourists. Influencers spread 'social' content that can generate many interactions, through which, depending on their recognised reliability, they are able to influence their followers (Murphy et al., 2018).

In relation to the quality of the information, the danger of manipulating the data made available to consumers is of substantial importance (Kimura et al., 2007; Stieglitz and Dang-Xuan, 2013). The increasing weight of unofficial and semi-official spaces has contributed to reducing the aspect of trust creation because of the weight of judgements that are not always objective or may even be intentionally distorted (Karpovich, 2010). In this regard, with a seemingly risky parallel, the counterfeiting of products-a phenomenon that is widespread in the manufacturing industry-is moving or is likely to relocate with increasing importance in the field of tourism services through precisely 'constructed' information that is partially or totally different from reality (Murphy et al., 2018).

Moreover, the strong competition and the difficulty for consumers to orient their choice of destination in the composite world of information have favoured the emergence of international operators that are indirect influencers of demand through specialised sites, including Booking. com, Trivago, TripAdvisor and Expedia. These sites provide information 
mainly on accommodation and catering facilities, yet are capable of having a decisive influence on the choice of particular destinations or on the preference for trip duration and period (Hadjikakou, 2013). In practice, through the technique of 'reviews', customers can assign a rating to hospitality structures, which is translated successively into a Likert scale (usually from 1 to 10 or 1 to 5 ) and relative qualitative judgements (using adjectives such as 'fabulous', 'exceptional' and 'superlative').

In a study related to the behaviour of operators, it was difficult to estimate to what extent online information express autonomous and spontaneous judgements, and from which point they are constructed in an 'artificial' and misleading way by competitors or people that are not real clients.

The above discussion has indicated how tourists' behaviour is changing today, also in function of the profound changes in the sources and way of presenting information. If we recall the AIDA model (Della Corte, 2013; Della Corte and Sciarelli, 2005), a large role is played by both internet providers and means of transport. Social networks enable individuals to start word of mouth/mouse in real time. This generates a spontaneous process that is started and managed by the demand itself, mainly based on the concept of experiential marketing (Del Chiappa and Fortezza, 2017; Iaia et al., 2014; Pencarelli and Forlani, 2002). Therefore, we decided to interview a panel of experts to verify how today's firms perceive the evolution of the tourism sector in the digital era, taking into account the current stage of development of the model and its main characteristics (overlap between the communication and distribution process, dynamic packaging in the broader meaning, destinations becoming more accessible, different sources of inspiration for information searching, disintermediation and so forth) to answer the following research questions:

RQ1: How do tourists search for destination information?

RQ2: What are the main changes on the offer side, and what are the roles of the involved actors?

RQ3: What are the sources of inspiration nowadays, and how easy is it for tourists to select and use them?

\section{Methodology}

To answer our research questions, we completed an experimental empirical analysis based on the method of a panel of experts (Lee et al., 2010). This allowed verification of what the experts thought and perceived about the topic, and determined whether our critical observations and research questions had the right orientation towards a scientific study of the issue.

Acknowledging the need for applied expertise, the panel of experts was drawn by privileged testimonials, representatives of different tourism firms and specialists in both online and offline media (such as national and international representatives of the most important operators of tourist firms and airline companies). This methodology aligned well with the aim of the research, since the selected experts were knowledgeable about the
Fabiana Sciarelli

Valentina Della Corte

Giovanna Del Gaudio

The evolution of tourism in

the digital era: the case of a tourism destination 
sinergie Vol. 36, N. 105, 2018

topic according to the overlapping vision between demand and offer. The expert panel was designed using the following categories: (1) tourism firms in the city of Naples, such as accommodation firms, tour operators and transportations firms; (2) managers involved in managing hotel chains and destinations; and (3) tourism sector associations with evidence of expertise in destination strategic management and marketing.

More precisely, the snowball sampling method was used, based on referrals from initial participants to generate other respondents. To secure participation, emails were sent between November and December 2017.

The experts were invited to participate via email through a letter written by the academic researchers. Two focus groups were organised. We studied the experts' opinions on the information contribution of online travel agencies (such as Booking.com, Trivago and social media) and online social travel networking (such as TripAdvisor), as well as on the informative syndrome, with specific reference to Naples as a tourist destination. The choice of a specific tourist destination was necessary to enable a unit of analysis on which to base the opinions, thereby rendering them more concrete and not too general.

Naples is the third-largest city in Italy after Rome and Milan, ranked by population. We chose Naples as the destination to examine for several reasons. First, it can be defined according to the six 'As' (Buhalis, 2000; Della Corte 2009; Della Corte and Aria, 2014, 2016) shaped by the following components: access, accommodation, amenities, attractions, ancillary services and assemblage. When all these factors coexist, the tourist destination can be conceived as an organised place that is able to attract tourist flows autonomously. In addition, the resources of the territory (local attractions, knowledge and culture) are able to attract tourists from all over the world. This city is experiencing interesting development in tourism (Table 1) in terms of increases in tourism flows, and has always been characterised by a rather contradictory image-as dangerous, chaotic and dirty, yet infinitely fascinating and wonderful for its cultural resources (Della Corte et al., 2015).

Tab. 1: Tourist flows

\begin{tabular}{|c|c|c|}
\hline Year & Arrivals & Overnights \\
\hline 2011 & 918,485 & $2,166,518$ \\
\hline 2012 & 892,896 & $2,292,213$ \\
\hline 2013 & 706,784 & $2,991,317$ \\
\hline 2014 & 720,349 & $2,891,104$ \\
\hline 2015 & $1,137,903$ & $2,908,633$ \\
\hline 2016 & $1,238,214$ & $3,292,057$ \\
\hline
\end{tabular}

Source: Ept, 2017

The data show a huge increase (+52\%) of overnight stays from 2011 to 2016. There are no data available for the period 2016 to 2018, yet there has been a huge increase in airport flows and connections, in visitors to museums (between $+10 \%$ and $+15 \%$ ) (MIBACT, 2016) and in hotels' rates of occupancy (constantly higher than $70 \%$ ). 
In recent years, the destination has known some positive experiences, such as advances in accessibility, a more widespread and positive image (both on television, in cinemas, in journals and in newspapers), a consistent increase in hospitality structures and subsequently in beds available (thereby hosting a higher number of tourist flows) and a more qualified professionality among the different firms in the sector. However, there remain serious and unresolved problems, such as the lack of a clear marketing strategy by local institutions, both offline and on the web, and lack of a local pivotal actor and business networks.

Recently, some lists of international rankings (such as in The Telegraph and Business Insider) declared that Naples is in the top five list of Italian destinations, stating that 'If Rome, Florence and Venice are world class, then Milan and Naples are not far behind: almost as rich culturally, and just as tempting in terms of eating, drinking and as springboards for other Italian destinations' (The Telegraph, 2018).

During recent years, 'much has been done recently to tidy up the center' (The Telegraph, 2018) and a series of strategic projects have been developed (such as DATABENC and URBACT). For example, the District of High Technology for Cultural Heritage (DATABENC) can be defined as an accelerator in creating an advanced cultural district to bridge the existing gaps in the strategic management approach of both the cultural and environmental heritage in its interconnections with the tourism industry. This district aims to use technology for the preservation and valorisation of the cultural heritage of the city of Naples. These projects have a socio-territorial value, characterised by an active pull of actors and firms. We conducted in-depth research on this topic, based on the variables illustrated in Table 2. The selection of these variables and their relative proxies originated from our review of the literature. Among the wide universe of the variables, the following variables summarise, according to an overlapping perspective between offer and demand, those representing the key issues in the digital era.

Tab. 2: Variables and proxies

\begin{tabular}{|l|l|}
\hline Variable & Proxies \\
\hline Information searching & - Existence of websites, social network pages and tourist communities \\
& - - Destination information on the internet \\
& - Influence of online information \\
& - Online prices of tourist products \\
& - Secure information about destinations \\
\hline E-service quality & - Expected quality of online services pleases tourists \\
& - Online quality service meets tourists' needs and expectations \\
& - View of online clean environment attracts tourism \\
& - Reasonable cost of tourism product attracts tourists \\
\hline E-word of mouth & - Friendliness, politeness and respect for tourists \\
& - Online messages to travellers about destination awareness \\
& the positive experience from previous travellers encourages other \\
& tourists to travel to the same destination; negative messages about \\
& the destination psychologically affect potential tourists \\
\hline Tourist satisfaction & - Most tourists have a positive view about this destination \\
& - Most tourists have a negative view about this destination \\
\hline
\end{tabular}

Source: Adapted from Kotoua and Ilkan (2017)
Fabiana Sciarelli Valentina Della Corte Giovanna Del Gaudio The evolution of tourism in the digital era: the case of a tourism destination 
Vol. 36, N. 105, 2018

The analysis was conducted on the basis of the most relevant sources deducted from the literature, as discussed in the first part of the paper.

\section{Results and discussion}

According to the panel of experts, Naples' promotion of tourist offers is still fragmented because there is no unique destination management system, but a variety of websites and social networks where tourists can obtain information during the pre-stage trip and the on-stage trip. Thus, the tourist image of Naples in terms of information is not coordinated.

The answers and reflections obtained through the panel of experts proceeded in the same direction, and the varied competences of the interviewed experts enriched and confirmed the complexity of this topic. According to some operators, tourists search information not only through local websites or social networks' fan page, but also through websites that deal with tourist information of Italy. For example, this is the case of visititaly.it-a website with connected social network pages with the function of being an Italian tourist guide. This website offers reservations and research for hotels, travel experiences, holidays in Italy, weather and maps. On this page, Naples, with its main attractors and experiences, has huge visibility.

Further, the experts highlighted the typical traits of Naples and its tourist products that can be defined as experiential (such as the Naples Vespa Tour, walking tour discovering the "esoteric version of the city of Naples"). These features make the search for information more oriented towards the experiences of living in the city, rather than the other components of the travel. This highlights the importance of websites such as viator.com, where tourists can book a special tour, or Booking.com and Airbnb to book accommodation. Hence, there are single online portals acting as 'dominus' of this sector, where information is spread out through e-word of mouth and can both negatively and positively influence the purchase of a single service, rather than the destination itself.

According to the experts, destination information on the internet is only slightly useful because it is not centralised or connected to a booking engine. Further, the experts asserted that the existing reviews do not always represent the prevailing target. Therefore, Naples has a rather chaotic and disorganised online presence. Hence, destination information is not satisfying in terms of content. The lack of a systemic and coordinated offer generates a situation of chaos for information search, e-quality and e-word of mouth. Today, the management of tourist information is not the result of a strategic and coordinated process, but a spontaneous process without a clear strategic vision, and where some actors (such as accommodation providers-Booking.com and Airbnb) and some influencers (such as bloggers or social networks-Visit Naples, Napoli da Vivere and InfoTurismoNapoli) offer some information and subsequently guide the choice on the destination, also in function of the good relationship between quality and price that characterizes the Neapolitan offer system.

In addition, the viewed online information that has a strong influence on tourist purchases is connected with the food and beverage experience. 
Tourists look for the best restaurants and pizzerias, as well as for the experience of street food.

The experts highlighted that sales are individual and not collective, and that further efforts are necessary to capitalise the sales of tourist products. With reference to the prices of tourism products online, the operators stressed that attention to the existence of price should be more concentrated on the single service, rather than on the existence of a dynamic package that combines the various components of the destination. Further, they asserted that one of the main strengths of the destination and its single services is the 'value for money' relationship, thereby confirming our previous observations regarding the role of internet providers in promoting Naples.

According to the experts, for the case of Naples, the informative syndrome must be strengthened during the induced level of marketing (pre-trip stage and purchase stage) and during the organic phase, through the actors that act as the best communicators and ambassadors of the destination (such as taxi drivers and transport firms). This would require specific training programs for these categories.

The panel of experts agreed on the role of Naples International Airport as the pivotal actor for promoting the city and for a series of initiatives to enhance the destination image. The lack of a destination management organisation and the contextual proactive capabilities of the airport's top managers have favoured the process of destination promotion by Naples International Airport. For example, the airport has implemented an innovative project called '\#Naplestoday' to promote the city of Naples through digital channels (via storytelling, content and photographs disseminated on the internet) by national and international bloggers that describe Naples and its tourist products to reach a wider international public. Hence, the most influential bloggers around the world are able to promote Naples as a tourist destination. In the same direction, the panel of experts asserted that future promotion strategies must follow this approach.

In regard to the process of information searching and e-service quality and, more precisely, destination information on internet, the operators asserted that one of the most critical points is the prevalence of information in the Italian language, rather than in other languages. Basic information about historic and cultural attractions is presented in different languages, yet daily events, updated things to do and other initiatives are essentially presented in Italian. In regard to tourist satisfaction, the operators asserted that $90 \%$ of tourists have a positive view of this destination. The case of Naples shows that the experiences of previous travellers can both encourage other tourists to travel to the same destination, and negatively affect views of the destination. The positive experiences of previous travellers encourage other tourists to travel to the same destination when reviews describe the folklore of Naples and the real experiences of living in the destination. In contrast, Naples is still considered a dangerous city, and this information affects the views of potential tourists. In this regard, the experts asserted that is necessary to work on developing appropriate management of communication strategies.
Fabiana Sciarelli

Valentina Della Corte

Giovanna Del Gaudio The evolution of tourism in

the digital era: the case of a tourism destination 
sinergie Vol. 36, N. 105, 2018

Hence, the answer to RQ1-'How do tourists search for destination information?'-is connected with the fact that tourists search for information from local (single local firms and public websites), national (Italian websites and social networks) and international (bloggers and social media) sources. Tourists search for experiences, rather than single tourist products. However, they do not always find exhaustive and clear information because of an institutional lack of communication and promotion.

With reference to RQ2-'What are the main changes on the offer side, and what are the roles of the involved actors?'-both the theoretical part and case study analysis demonstrated that the advent of the internet and decrease of commercial mediation by classical intermediaries (tour operators and travel agencies) favour the big players. The analysis also showed that there is chaotic and sometimes confused information on the destination, which renders the decision process much more difficult for tourists, unless very highly motivated.

The panel of experts agreed on the necessity of stronger cooperation in this field, with the role of the Naples International Airport having the potential to be strengthened by an organised and validated process and structure. Further, different actors should coordinate their information strategies to avoid the fragmentation effects and the related asymmetric information between the demand and offer side. This also proves how the process is increasingly complex and full of actors that provide inputs of different types of information, and continuously interact with tourists and sometimes between themselves, as explained in our model.

With reference to RQ3-'What are sources of inspiration nowadays, and how easy is it for tourists to select and use them?'-as aforementioned, the panel of experts agreed that e-word of mouth is of paramount importance in the process of destination choice, even if, in the case of Naples, the current online reviews refer more to single services (such as hotels and restaurants), rather than the destination itself. In this direction, further efforts can be implemented to create a guided process promoted by the actors of the tourism offer. Hence, previous tourists' experiences influence the choice of a destination both positively and negatively. The positive effects can be observed in tourists' willingness to partake in an experiential tourist product, while the negative reviews lead to tourists choosing Naples as a city for daily tours, rather than to stay overnight. To cite an online example: 'the city still has an edge and bustle that can be challenging, especially in summer heat. As a result, you may want to come here on a day trip from nearby Sorrento, less than an hour by train, or from the island of Capri or the Amalfi Coast' (The Telegraph, 2018).

\section{Limitations, conclusions and first hints for research and managerial agenda}

This paper has discussed the changes occurring in tourism in the digital era, and the connected information syndrome issue. We performed an initial empirical test, which can be considered a first step of a wider research 
project on the topic, connected with Industry 4.0 and internet of things (IOT) further developments. From this perspective, the tourism sector is very interesting because it began using the new ICT tools connected with social and web media marketing even before some manufacturing industries did. However, because of the fact that these tools are more open in their structure, there is a high risk, especially in services, of a redundancy of comments and a lack of trustful information that renders the decision process less clear and more uncertain. This aspect was analysed empirically with reference to a panel of experts, focusing the analysis on the field. For this reason, our findings cannot be generalised to the entire population of destinations. Nevertheless, this paper aimed to develop a 'state of art' within a precise context that can be used as a starting point to highlight the strengths and weaknesses of the current local offers in terms of tourist information management. This topic also requires analysis of the demand, which will be the object of further research.

The tourism business is changing profoundly in the era of globalisation and digitalisation. In spite of the critical times, of both economic and political nature, the responses given by both offer and demand have been appropriate, considering the actual context. In other words, although the risk factors and uncertainty during the tourist decision-making process have increased, the degree of professionalism and digital opportunities have been enlarged.

Fake news can express both a positive or negative judgement that does not coincide with reality. These reviews can be written to support a certain firm or destroy a brand's reputation (Cinman, 2008). The critical point of fake news can become greater and can be used as a competitive weapon, given the attention shown by tourists to so-called 'ratings'. Further, there is the need to apply "useful filters" for access to social networks and to the internet in general. If the problem of the abundance of information available in the digital age is added to the problem of the information's veracity, the concept of informative syndrome becomes better understood.

In regard to the demand side, the huge amount of information imposes a strict process of control on the authenticity and accuracy of informative elements. On the offer side, the tourist actors are trying to improve aspects of flexibility and guarantee for the customers (Xiang and Gretzel, 2010). The offer of flexibility (such as free cancellation or differentiation according to days and hours) can create wider stimuli for tourists. Further, the possibility of expanding the degree of flexibility is connected with large organisations that can exploit the power of the network.

The role of tour operators is lowering, competition is becoming increasingly aggressive and a few firms are leading the online market. This has caused travel agencies to almost disappear in the face of online travel agencies and internet providers, apart from specific niche initiatives. As aforementioned, the main players are airline companies (with airports) and internet providers. The increasing role and functions of posts, big data and target profile analyses run the risk of generating a backway process that has excessive dependence on demand and demand analyses (as confirmed by the increasing request for data analysts in firms) (Umachandran et al., 2017). This paradoxically expresses a more adaptive approach in the face of
Fabiana Sciarelli

Valentina Della Corte

Giovanna Del Gaudio

The evolution of tourism in

the digital era: the case of a tourism destination 
sinergie Vol. 36, N. 105, 2018

demand, as opposed to entrepreneurial Schumpeterian creativity to foster innovation.

Such facts support our deep concern regarding the informative syndrome. From a certain perspective, research can start examining the direct connections with the home destinations, and examining the destinations that are subsequently connected through a point-to point system.

With reference to the results of this research, which deserve to be further tested, in our opinion, the central focus provided by both the theoretical and empirical parts is the opportunity or need (given the significance of competition in a sector that is destined to become increasingly important) to establish a guaranteed authority in the tourism sector at the European level and international level. The correctness and reliability of information is an essential factor in this era, where the economy is oriented in the direction of effectiveness and transparency, and European legislators cannot ignore this "state of art". The quality of information and professionalism are of fundamental importance in a sector characterised by dynamism and turbulence.

In this chaos, a question arises about the future role of destination management (Della Corte and Sciarelli, 2012; Martini, 2005) and what its effect will be on city destinations. The capacity to build and communicate a destination image is increasingly characterised by distinctive, unique and exclusive emotional traits that generate specific experiences that cannot be duplicated or substituted. These aspects, combined with the cultural and individual socio-demographic factors previously outlined, can help make tourist destinations less vulnerable to abrupt changes in demand, as well as in facing crisis situations promptly. In other words, competition is mainly based on local systems of tourist offers (Della Corte, 2000) and on its capacity to be able to generate sustainable competitive advantage, through the experience that the demand itself communicates through its hints that we may be returning to genuineness and substance.

\section{References}

ASCHAUER W. (2009), "International Colloquium of Tourism and Leisure 5.-8. Mai 2008 in Chiang Mai”, Zeitschrift für Tourismuswissenschaft, vol. 1, n. 1, pp. 101-103.

BARNEY J. (1991), "Firm resources and sustained competitive advantage", Journal of management, vol. 17, n. 1, pp. 99-120.

BIEGER T., WITTMER A. (2006), "Air transport and tourism-Perspectives and challenges for destinations, airlines and governments", Journal of Air Transport Management, vol. 12, n. 1, pp. 40-46.

BRONDONI S.M. (2000), Patrimonio di marca e gestione d'impresa, Symphonya. Emerging Issues in Management, Giappichelli, Torino.

BRUNETTI F., TESTA F., UGOLINI M. (2011), "Il cliente nell'agenzia viaggi", Sinergie, n. 66, pp. 181-211.

BUHALIS D. (2000), "Marketing the competitive destination of the future", Tourism Management, vol. 21, n. 1, pp. 97-116. 
BUHALIS D., LAW R. (2008), "Progress in information technology and tourism management: 20 years on and 10 years after the Internet-The state of eTourism research", Tourism management, vol. 29, n. 4, pp. 609-623.

BUHALIS D., O'CONNOR P. (2005), "Information communication technology revolutionizing tourism", Tourism recreation research, vol. 30, n. 3, pp. 7-16.

CASALÓ L.V., FLAVIÁN C., GUINALÍU M., EKINCI Y. (2015), "Avoiding the dark side of positive online consumer reviews: Enhancing reviews' usefulness for high risk-averse travelers", Journal of Business Research, vol. 68, n. 9, pp. 1829-1835.

CHIARINI A., VAGNONI E. (2017), "Strategic management of industry 4.0. An exploratory research", Atti del convegno Sinergie-Sima 2017 - Value CoCreation: management challenges for business and society, pp. 220-224.

CINMAN J. (2008), "Tough to manage reputations in a digital world: online", Journal of Marketing, vol. 2008, n. Jun/Jul 2008, p. 42.

COSHALL J.T. (2009), "Combining volatility and smoothing forecasts of UK demand for international tourism”, Tourism Management, vol. 30, n. 4, pp. 495-511.

CROTTS J.C., ERDMANN R. (2000), “Does national culture influence consumers' evaluation of travel services? A test of Hofstede's model of cross-cultural differences", Managing Service Quality: An International Journal, vol. 10, n. 6, pp. 410-419.

DE NISCO A., MAINOLFI G., MARINO V., NAPOLITANO M.R. (2012), "Tourism experience, country image and postvisit intentions: a study on international tourists in Italy", International Marketing and the Country of Origin Effect. The Global Impact of Made in Italy, Edward Elgar Publishing, Cheltenham, pp. 65-80.

DECROP A. (1999), Tourists' decision-making and behavior processes, The Haworth press, New York.

DEL CHIAPPA G., FORTEZZA F. (2017), "Analisi delle motivazioni alla base del turismo matrimoniale: un'indagine esplorativa", Sinergie Italian Journal of Management, vol. 34, n. 101, pp. 141-157.

DELLA CORTE V. (2000), La gestione dei sistemi locali di offerta turistica, Cedam, Padova.

DELLA CORTE V. (2009), Imprese e Sistemi Turistici. Il management, Egea, Milano.

DELLA CORTE V. (2013), Imprese e Sistemi Turistici. Il management, II Edizione, Egea, Milano.

DELLA CORTE V., ARIA M. (2014), "Why strategic networks often fail: Some empirical evidence from the area of Naples", Journal of Tourism Management, vol. 45 , pp. 3-15.

DELLA CORTE V., ARIA M. (2016), "Coopetition and sustainable competitive advantage. The case of tourist destination", Journal of Tourism Management, vol. 54 , pp. 524-540.

DELLA CORTE V., SCIARELLI M. (2012), Destination management e logica sistemica. Un confronto internazionale, Giappichelli, Torino.

DELLA CORTE V., SCIARELLI M., CASCELLA C., DEL GAUDIO G. (2015), "Customer satisfaction in tourist destination: The case of tourism offer in the city of Naples", Journal of Investment and Management, vol. 4, n. 1-1, pp. 39-50.

DOLNICAR S. (2005), "Understanding barriers to leisure travel: Tourist fears as a marketing basis", Journal of Vacation Marketing, vol. 1.1, n. 3, pp. 197-208.
Fabiana Sciarelli

Valentina Della Corte

Giovanna Del Gaudio

The evolution of tourism in

the digital era: the case of a

tourism destination 
sinergie Vol. 36, N. 105, 2018

DRAKOS K., KUTAN A.M. (2003), "Regional effects of terrorism on tourism in three Mediterranean countries”, Journal of Conflict Resolution, vol. 47, n. 5, pp. 621-641.

DUMAN T., KOZAK M. (2010), "The Turkish tourism product: Differentiation and competitiveness”, Anatolia, vol. 21, n. 1, pp. 89-106.

FOTIS J., BUHALIS D., ROSSIDES N. (2012), "Social media use and impact during the holiday travel planning process", in Fuchs M., Ricci F., Cantoni, L., eds. Information and Communication Technologies in Tourism, SpringerVerlag, Vienna, Austria, 13-24.

FRANCH M., MICH L., MARTINI U. (2001), "A method for the classification of relationships and information needs of tourist destination players", in Information and Communication Technologies in Tourism 2001. Proceedings of the International Conference in Montreal, Canada, 2001. Eds. Sheldon P.J., Woeber K.W., Fesenmaier D.R., Vienna: Springer, 2001, p. 42-51. Proceedings of: ENTER 2001, Montreal (Canada), 24 -27 April 2001.

FUCHS G., REICHEL A. (2011), "An exploratory inquiry into destination risk perceptions and risk reduction strategies of first time vs. repeat visitors to a highly volatile destination", Tourism Management, vol. 32, n. 2, pp. 266-276.

FUCHS M., HÖPKEN W., LEXHAGEN M. (2014), "Big data analytics for knowledge generation in tourism destinations-A case from Sweden", Journal of Destination Marketing \& Management, vol. 3, n. 4, pp. 198-209.

GRETZEL U., YOO K.H. (2008), "Use and impact of online travel reviews", in Information and communication technologies in tourism 2008, SpringerVerlag, Vienna, Austria pp. 35-46.

GUTMAN Y (2009), "Where do we go from here: The pasts, presents and futures of Ground Zero", Memory Studies, vol. 2, n. 1, pp. 55-70.

HADJIKAKOU M., CHENOWETH J., MILLER, G. (2013), "Estimating the direct and indirect water use of tourism in the eastern Mediterranean", Journal of Environmental Management, vol.1, n. 14, pp. 548-556.

HAN H., HSU L. T. J., LEE, J. S. (2009), "Empirical investigation of the roles of attitudes toward green behaviors, overall image, gender, and age in hotel customers' eco-friendly decision-making process", International Journal of Hospitality Management, vol. 28, n. 4, pp. 519-528.

HAYS S., PAGE S. J., BUHALIS D. (2013), "Social media as a destination marketing tool: its use by national tourism organisations", Current issues in Tourism, vol. 16, n. 3, pp. 211-239.

IAIA L., FAIT M., CAVALLO F., SCORRANO P., MAIZZA A. (2014), "Experiential marketing per il brand-land dei prodotti tipici: diventare marchio comunicando il territorio", Atti del XXVI Convegno annuale di Sinergie 2014 - Manifattura: quale futuro?, Università di Cassino e Lazio Meridionale, $13^{\text {th }}-14^{\text {th }}$ November 2014.

KARPOVICH A.I. (2010), “Theoretical approaches to film-motivated tourism”, Tourism and Hospitality Planning \& Development, vol. 7, n. 1, pp. 7-20.

KIM S.S., WONG K.K., CHO M. (2007), "Assessing the economic value of a world heritage site and willingness-to-pay determinants: A case of Changdeok Palace", Tourism Management, vol. 28, n. 1, pp. 317-322.

KIMURA M., SAITO K., NAKANO R. (2007), "Extracting influential nodes for information diffusion on a social network”, AAAI, vol. 7 , pp. 1371-1376. 
KOO B., MANTIN B., O'CONNOR P. (2011), "Online distribution of airline tickets: Should airlines adopt a single or a multi-channel approach?", Tourism Management, vol. 32, n. 1, pp. 69-74.

KOTOUA S., ILKAN M. (2017), “Tourism destination marketing and information technology in Ghana”, Journal of Destination Marketing \& Management, vol. 6, n. 2, pp. 127-135.

KOZAK M., CROTTS J.C., LAW R., "The Impact of the Perception of Risk on International Travellers", International Journal of Tourism Research, vol. 9, n. 4, July 2007, pp. 233 - 242

UMACHANDRAN K., FERDINAND D.S., JURČIĆ I., DELLA CORTE V. (2017), "e-commerce: A Social Engagement Tool", OSR Journal of Economics and Finance (IOSR-JEF), vol. 8, n. 5, pp. 60-64.

LARSEN S., WOLFF K. (2016), “Exploring assumptions about cruise tourists' visits to ports”, Tourism Management Perspectives, vol. 17, January 2016, pp. 4449.

LEE C.F., HUANG H.I., YEH H.R. (2010), "Developing an evaluation model for destination attractiveness: Sustainable forest recreation tourism in Taiwan", Journal of Sustainable Tourism, vol. 18, n. 6, pp. 811-828.

LI G., WONG K.K., SONG H., WITT S.F. (2006), “Tourism demand forecasting: A time varying parameter error correction model”, Journal of Travel Research, vol. 45, n. 2, pp. 175-185.

LITVIN S.W., GOLDSMITH R. E., PAN B. (2008), "Electronic word-of-mouth in hospitality and tourism management", Tourism Management, vol. 29 n. 3, pp. 458-468.

LUQUE-MARTÍNEZ T., ALBERTO CASTAÑEDA-GARCÍA J., FRÍAS-JAMILEN D.M., MUÑOZ-LEIVA F., RODRÍGUEZ-MOLINA M.A. (2007), "Determinants of the use of the internet as a tourist information source", The Service Industries Journal, vol. 27, n. 7, pp. 881-891.

MANGION M.L., DURBARRY R., SINCLAIR M.T. (2005), “Tourism competitiveness: price and quality", Tourism Economics, vol. 1, n. 1, pp. 4568.

MARTINI U. (2005), Management dei sistemi territoriali. Gestione e marketing delle destinazioni turistiche, Giappichelli, Torino.

MCCABE S., LI X.R. (2017), "Digging deeper into decision-making of Chinese long-haul outbound tourists: A two-stage preference-estimation approach", Journal of Destination Marketing \& Management, vol. 6, n. 3, pp. 267-275.

MICH L. (2011) "La web presence delle destinazioni turistiche. Facebook in Tourism”, eBook, FrancoAngeli, Milano.

MICH L., FRANCH M., GAIO L. (2003), "Evaluating and designing web site quality”, IEEE MultiMedia, vol. 10, n. 1, pp. 34-43.

MICH, L., FRANCH, M., MARZANI, P. (2004), "Guidelines for excellence in the web sites of tourist destinations: A study of the regional tourist boards in the Alp", IADIS International Conference e-Society.

MICHOPOULOU E., BUHALIS D. (2008), "Performance measures of net-enabled hypercompetitive industries: The case of tourism", International Journal of Information Management, vol. 28, n. 3, pp. 168-180.

MORAKABATI Y., KAPUŚCIŃSKI G. (2016), "Personality, risk perception, benefit sought and terrorism effect", International Journal of Tourism Research, vol. 18 , n. 5, pp. 506-514.
Fabiana Sciarelli

Valentina Della Corte

Giovanna Del Gaudio

The evolution of tourism in

the digital era: the case of a

tourism destination 
sinergie

Vol. 36, N. 105, 2018

MORGAN N., PRITCHARD A., PRIDE R. (2007), Destination branding, Routledge, UK.

MURPHY J., GRETZEL U., PESONEN J., ELORINNE A. L., SILVENNOINEN, K. (2018), "Household Food Waste, Tourism and Social Media: A Research Agenda", in Information and Communication Technologies in Tourism, January 2018, Springer, Cham, pp. 228-239.

NAPOLITANO M.R., DE NISCO A. (2004), "Vantaggio competitivo territoriale e configurazioni distrettuali nel turismo. Il ruolo e le potenzialità del cluster", G. Marotta (a cura di). Nuovi turismi e politiche di gestione nella destinazione. Situazione e prospettive per le aree rurali della Campania, Franco Angeli, Milano.

PAN B., FESENMAIER D.R. (2006), "Online information search: vacation planning process”, Annals of Tourism Research, vol. 33, n. 3, pp. 809-832.

PENCARELLI T., FORLANI F. (2011), "Il marketing dei distretti turistici-sistemi vitali nell'economia delle esperienze", Sinergie, n. 58, pp. 231-277

PIKE S. (2009), "Destination brand positions of a competitive set of near-home destinations", Tourism management, vol. 30, n. 6, pp. 857-866.

PIZAM A., REICHEL A. (1996), "The effect of nationality on tourist behavior: Israeli tour-guides' perceptions", Journal of Hospitality and Leisure Marketing, vol. 4, n. 1, pp. 23-49.

PRIDEAUX B. (2000), "The role of the transport system in destination development", Tourism management, vol. 21, n. 1, pp. 53-63.

PUAR J. K. (2002), "Circuits of queer mobility: Tourism, travel, and globalization", GLQ: A Journal of Lesbian and Gay Studies, vol. 8, n. 1, pp. 101-137.

REISINGER Y., MAVONDO F. (2005), “Travel anxiety and intentions to travel internationally: Implications of travel risk perception”, Journal of Travel Research, vol. 43, n. 3, pp. 212-225.

RITA P. (2000), “Tourism in the European Union”, International Journal of Contemporary Hospitality Management, vol. 12, n. 7, pp. 434-436.

ROEHL W.S., FESENMAIER D.R. (1992), "Risk perceptions and pleasure travel: An exploratory analysis", Journal of Travel research, vol. 30, n. 4, pp. 17-26.

SCIARELLI S., DELLA CORTE V. (2011), "Il comportamento del turista in condizioni di forte incertezza decisionale”, Sinergie, n. 66, pp-137-152.

SIGALA M. (2011), "eCRM 2.0 applications and trends: The use and perceptions of Greek tourism firms of social networks and intelligence", Computers in Human Behavior, vol. 27, n. 2, pp. 655-661.

SIMEON M.I., BUONINCONTRI P., CINQUEGRANI F., MARTONE A. (2017), "Exploring tourists' cultural experiences in Naples through online reviews", Journal of Hospitality and Tourism Technology, vol. 8, n. 2, pp. 220-238.

SIMPSON P.M., SIGUAW J.A. (2008), "Destination word of mouth: The role of traveler type, residents, and identity salience", Journal of Travel Research, vol. 47, n. 2, pp. 167-182.

SMALLMAN C., MOORE K. (2010), "Process studies of tourists'decisionmaking", Annals of tourism research, vol. 37, n. 2, pp. 397-422.

SÖNMEZ S.F., GRAEFE A.R. (1998), "Determining future travel behavior from past travel experience and perceptions of risk and safety", Journal of Travel Research, vol. 37, n. 2, pp. 171-177. 
STAKE R.E. (2013), Multiple case study analysis, Guilford Press, New York. STAMBOULIS Y., SKAYANNIS P. (2003), "Innovation strategies and technology for experience-based tourism", Tourism Management, vol. 24, n. 1, pp. 35-43.

STIEGLITZ S., DANG-XUAN L. (2013), "Emotions and information diffusion in social media-sentiment of microblogs and sharing behavior", Journal of Management Information Systems, vol. 29, n. 4, pp. 217-248.

UMACHANDRAN K., FERDINAND D.S., JURČIĆ I., DELLA CORTE V. (2017), "e-commerce: A Social Engagement Tool", IOSR Journal of Economics and Finance, vol. 8, n. 5, pp. 60-64.

URRY J. (2003), “Social networks, travel and talk1", The British Journal of Sociology, vol. 54, n. 2, pp. 155-175.

WEI Y.W. (2013), "Exploring the Cultural Heritage Landscape in Web 3.0 Era Tourism", Doctoral dissertation, Politecnico di Torino.

WÖBER K.W. (2003), "Information supply in tourism management by marketing decision support systems", Tourism Management, vol. 24, n. 3, pp. 241-255.

WORLD TRADE ORGANIZATION (2016), "The economic impact of travel \& tourism”, World Trade Organization, World Travel \& Tourism Council, London, UK.

WU D.C., LI G., SONG H. (2012), "Economic analysis of tourism consumption dynamics: A time-varying parameter demand system approach", Annals of Tourism Research, vol. 39, n. 2, pp. 667-685.

XIANG Z., GRETZEL U. (2010), "Role of social media in online travel information search", Tourism Management, vol. 31, n. 2, pp. 179-188.

YANG E.C.L., SHARIF S.P., KHOO-LATTIMORE C. (2015), “Tourists' risk perception of risky destinations: The case of Sabah's eastern coast", Tourism and Hospitality Research, vol. 15, n. 33, pp 206-221.

\section{Academic or professional position and contacts}

\section{Fabiana Sciarelli}

Researcher and Adjunct Professor of Management

"L'Orientale" University of Naples - Italy

e-mail: fsciarelli@unior.it

\section{Valentina Della Corte}

Associate Professor of Management

University of Naples Federico II - Italy

e-mail: valentina.dellacorte@unina.it

\section{Giovanna del Gaudio}

Phd in Tourism Management

University of Naples Federico II - Italy

e-mail: giovanna.delgaudio@unina.it

Fabiana Sciarelli

Valentina Della Corte

Giovanna Del Gaudio

The evolution of tourism in

the digital era: the case of a tourism destination

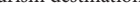

